\title{
CARA PENGAWETAN IKAN MAS (Cyprinus carpio L) DENGAN MENGGUNAKAN FERMENTASI LIMBAH KUBIS (Brassica oleracea)
}

(Waste Utilization of Cabbage (Brassica oleracea) as a Preservative Tilapia (Oreochromis sp)

\author{
Misril Fuadi dan Surnaherman \\ Fakultas Pertanian Universitas Muhammadiyah Sumatera Utara \\ fuadgucy@gmail.com
}

\begin{abstract}
The research on the utilization of waste cabbage (Brassica oleracea) as a preservative tilapia (Oreochromis sp) with RAL factorial method with 2 replications.The first factor is the concentration of $\mathrm{NaCl}$ with a password (N) which consists of 4 levels, namely: $\mathrm{N}_{1}=1 \%, \mathrm{~N}_{2}=2 \%, \mathrm{~N}_{3}=3 \%, \mathrm{~N}_{4}=4 \%$. Factor II is a password storage time $(\mathrm{P})$ which consists of 4 levels, namely: $\mathrm{P}_{1}=1$ days, $\mathrm{P}_{2}=3$ days, $\mathrm{P}_{3}=$ 5 days, $\mathrm{P}_{4}=7$ days. The parameters observed from the data analysis showed that $\mathrm{NaCl}$ concentration and storage time significantly affected the protein content, moisture content, organoleptic aroma, texture organoleptic tests,and organoleptic color not significant.
\end{abstract}

Keywords: longdepository,concentration sodium chloride

\section{A. PENDAHULUAN}

Ikan merupakan bahan pangan yang mudah membusuk. Hal ini dikarenakan daging ikan merupakan substrat yang ideal untuk kehidupan dan pertumbuhan mikroorganisme pembusuk, terutama bakteri. Kandungan air yang terdapat di dalam daging ikan cukup tinggi sehingga sangat sesuai untuk pertumbuhan bakteri. Oleh sebab itu pengawetan ikan perlu diketahui semua lapisan masyarakat. Pengawetan ikan secara tradisional bertujuan untuk mengurangi kesempatan bagi bakteri untuk berkembang biak. Untuk mendapatkan hasil awetan yang bermutu tinggi diperlukan perlakukan yang baik selama proses pengawetan seperti : menjaga kebersihan bahan dan alat yang digunakan, menggunakan ikan yang masih segar, serta garam yang bersih (Irawan, 1995).

Ikan segar merupakan salah satu komoditi yang mudah mengalami kerusakan (high perishable food). Kerusakan ini dapat disebabkan oleh proses biokimia maupun oleh aktivitas mikrobiologi. Kandungan air pada ikan umumnya tinggi mencapai 56,79\% sehingga sangat memungkinkan terjadinya reaksi-reaksi biokimiawi oleh enzim yang berlangsung pada tubuh ikan segar. Semantara itu, kerusakan secara mikrobiologis disebabkan karena aktivitas mikroorganisme terutama bakteri (Daulay dan Rahman, 1992).

Penanganan pascapanen pada produk perikanan merupakan hal yang penting untuk dicermati karena akan berpengaruh pada kualitas produk yang akan dihasilkan dan nilai jualnya. Namun, penanganan pascapanen pada tingkat nelayan tradisional atau pembudidaya masih rendah. Ada bermacam-macam pengawetan ikan, antara lain dengan cara: penggaraman, pengeringan, pemindangan, pengasapan, peragian, dan pendinginanikan (Irawan, 1992).

Penyimpanan ikan pada suhu rendah juga dapat menghambat pertumbuhan bakteri pembusuk karena sebagian besar bakteri tidak dapat hidup pada suhu

5-10 ${ }^{\circ} \mathrm{C}$. Sebagian besar penanganan ikan masih menggunakan es sebagai media pengawet. Es dapat memperpanjang masa simpan ikan, namun ada beberapa bakteri pembusuk yang dapat bertahan pada suhu rendah, sehingga diperlukan kombinasi penggunaan zat antibakteri sebagai bahan pengawet. Namun, meskipun telah disimpan pada suhu rendah masih ada saja bakteri pembusuk yang dapat bertahan. Masa simpan ikan dapat diperpanjang dengan hasil fermentasi limbah kubis yang menghasilkan asam laktat. Oleh karena itu diperlukan penambahan bakteri asam laktat 
pada ikan untuk memperpanjang kualitas dan masa simpan ikan. Penggunaan bahan alami dimanfaatkan sebagai bahan pengawet alami untuk ikan yang setelah pascapanen agar tetap terjaga kualitas dan gizi yang terkadung dalam ikan tersebut. Pemanfaatan limbah kubis sebagai bahan pengawet alami ikan segar digunakan untuk mengawetkan ikan secara alami agar penyalahgunaan pengawet yang bersifat tidak menyehatkan bagi tubuh manusia tidak digunakan lagi. Akibat maraknya pengawet zat kimia yang dapat membahayakan tubuh manusia, yang disalahgunakan sebagai pengawet ikan segar (Pracaya, 1987).

Salah satu komoditi hortikultura/sayursayuran seperti Kubis (Brassica oleracea) merupakan sayuran yang cukup dikenal, banyak diproduksi, mudah didapat dan murah harganya. Kubis juga merupakan salah satu jenis sayuran yang banyak tumbuh di daerah dataran tinggi. Sayuran ini bersifat mudah layu, rusak dan busuk, sehingga menghasilkan limbah (bau) yang menjadi suatu permasalahan lingkungan. Limbah kubis yang membusuk inilah merupakan tempat hidupnya suatu bakteri yang dinamakan Lactobacillus plantarum, Lactobacillus delbrukil, Laktobacillus fermentum dan Lactobacillus brevis. Lactobacillusmerupakan suatu mikroorganisme yang berfungsi dalam pembentukan asam laktat dari laktosa. Dalam karya tulisan Suprihatin, dkk. 2010 menyebutkan proses fermentasi asam laktat terjadi karena adanya aktivitas bakteri laktat yang secara alami terdapat pada limbah daun kubis tersebut dan mengubah glukosa menjadi asam laktat pada kondisi anaerob dengan penambahan $\mathrm{Na}_{3} \mathrm{PO}_{4}$ secukupnya. Kubis mengandung asam laktat yang menyebabkan $\mathrm{pH}$ substrat turun hingga dibawah 5 sehingga dapat menghambat sejumlah bakteri perusak dan pembusuk makanan. Selain itu, hasil fermentasi kubis juga menghasilkan sejumlah vitamin khususnya B12 (Harjono, 1996).

Sistem pengawetan dengan metode fermentasi merupakan proses pengawetan pangan yang alami (ikan, hasil tanaman, daging, dll) dengan memanfaatkan kemampuan kelompok bakteri laktat, yaitu Lactobacillus plantarum, L. acidophylus, Leuconostoc mesenterousdes, Streptococcus faecalis, dan $S$. lactis. Pertumbuhan kelompok bakteri ini mampu menurunkan nilai $\mathrm{pH}$ substrat hingga 4,5 bahkan lebih rendah. Pada $\mathrm{pH}$ tersebut, pertumbuhan kelompok bakteri lain dapat dihambat. Proses fermentasi dapat dilakukan secara mudah, murah dan sederhana, aman dan tidak mengurangi nilai organoleptik bahan pangan (Amin, 2001).

Salah satu contoh bakteri yang dikenal luas adalah nisin, diproduksi oleh Lactobacillus lactis ssp. Nisin dapat menghambat pertumbuhan beberapa bakteri, yaitu Bacillus, Clostridium, Staphylococcus, dan Listeria. Senyawa bakteriosin yang diproduksi bakteri asam laktat dapat bermanfaat karena menghambat bakteri patogen yang dapat merusak makanan ataupun membahayakan kesehatan (Zaifbio, 2009).

\section{B. METODOLOGI \\ Bahan dan Alat}

Bahan penelitian yang digunakan dalam penelitian ini adalah limbah kubis, $\mathrm{NaCl}$, aquadest, dan ikan mas. Bahan kimia yang digunakan dalam penelitian ini adalah $\mathrm{NaCl}$, Katalisator (K2SO4+CuSO4), H2SO4, Aquadest, $\mathrm{NaOH}$, dan Methyl red.

Alat yang digunakan dalam penelitian ini adalah Erlemeyer, gelas ukur, pisau, saringan, sendok, telenan, saringan, batang pengaduk, baskom, timbangan analitik, timbangan, inkubator, labu kjeldahl, labu detilasi, pipet tetes, oven.

\section{Rancangan Penelitian}

Metode penelitian dilakukan dengan metode Rancangan Acak Lengkap (RAL) faktorial yang terdiri dari 2 faktor yaitu :

Faktor I : Konsentrasi $\mathrm{NaCl}(\mathrm{N})$ yang terdiri dari 4 taraf yaitu :

$$
\begin{aligned}
& \mathrm{N}_{1}=1 \% \\
& \mathrm{~N}_{2}=2 \% \\
& \mathrm{~N}_{3}=3 \% \\
& \mathrm{~N}_{4}=4 \%
\end{aligned}
$$

Faktor II : Lama Penyimpanan (P) yang terdiri dari 4 taraf yaitu :

$$
\begin{aligned}
& \mathrm{P}_{1}=1 \text { hari } \\
& \mathrm{P}_{2}=3 \text { hari } \\
& \mathrm{P}_{3}=5 \text { ha ri } \\
& \mathrm{P}_{4}=7 \text { hari }
\end{aligned}
$$

Banyaknya kombinasi perlakuan (Tc) adalah $4 \mathrm{x}$ $4=16$, maka jumlah ulangan (n) adalah sebagai berikut :

$$
\begin{aligned}
\text { Tc }(n-1) & \geq 15 \\
16(n-1) & \geq 15 \\
16 n-16 & \geq 15 \\
16 n & \geq 31
\end{aligned}
$$


$\mathrm{n} \geq 1,937 \ldots \ldots \ldots . .$. dibulatkan menjadi $\mathrm{n}=2$ maka untuk ketelitian penelitian, dilakukan ulangan sebanyak 2 (dua) kali.

\section{Model Rancangan Percobaan}

Penelitian ini dilakukan dengan Rancangan Acak Lengkap (RAL) faktorial dengan model Dimana :

$$
\tilde{Y} \mathbf{i j k}=\mu+\alpha \mathbf{i}+\beta j+(\alpha \beta) i j+\varepsilon i j k
$$

Ỹijk : Pengamatan dari faktor L dari taraf ke - i dan faktor P pada taraf $\mathrm{ke}-\mathrm{j}$ dengan ulangan $\mathrm{ke}-\mathrm{k}$.

$\mu \quad$ : Efek nilai tengah.

$\alpha \mathrm{i} \quad$ : Efek dari faktor L pada taraf ke - i.

$\beta \mathrm{j} \quad$ : Efek dari faktor P pada taraf ke $-\mathrm{j}$.

$(\alpha \beta)$ ij : Efek interaksi faktor L pada taraf ke - i dan faktor P pada taraf ke - j.

cijk $\quad$ : Efek galat dari faktor L pada taraf ke - i dan faktor P pada taraf ke - j dalam ulangan $\mathrm{ke}-\mathrm{k}$.

\section{Pelaksanaan Penelitian}

Larutan Limbah Kubis:

1. Limbah kubis dipilih dan dicuci berih.

2. Dipotong iris kecil - kecil dengan menggunakan pisau, potongan dirajang (diris - iris) bertujuan mempercepat proses fermentasi.

3. Ditimbang limbah kubis yang teleh diiris- iris sebanya 350 gram dan dimasukkan kedalam gelas ukur.

4. Ditambahkan $\mathrm{NaCl}$ kedalam gelas ukur yang berisi limbah kubis yang telah diiris - iris : $\mathrm{N}_{1}=1 \%, \mathrm{~N}_{2}=2 \%, \mathrm{~N}_{3}=3 \%, \mathrm{~N}_{4}=4 \%$.

5. Dicampurkan dengan Aqudes sebanyak 200 ml, kemudian diaduk dan tutup rapat menggunakan plastik klip warp.

6. Dimasukkan kedalam inkubator/inkubasi, dan disimpan selama 9 hari agar terjadinya fermentasi.

\section{Pengawetan Ikan Mas:}

1. Setelah 9 hari limbah kubis disimpan dan terjadinya fermentasi dalam limbah kubis, larutan limbah kubis disaring menggunakan saringan.

2. Ikan mas dibersihkan sisiknya dan dicuci bersih.

3. Selanjutnya masukkan ikan mas kedalam larutan limbah kubis yang telah disaring dan simpan disuhu ruangan; $\mathrm{P}_{1}=1$ Hari, $\mathrm{P}_{2}=3$ Hari, $\mathrm{P}_{3}=5$ Hari, $\mathrm{P}_{4}=7$ Hari.

\section{HASIL DAN PEMBAHASAN}

Dari hasil penelitian dan uji statistik.secara umum menunjukkan bahwa konsentrasi $\mathrm{NaCl}$ berpengaruh terhadap parameter yang diamati.

\section{Kadar Protein \\ Pengaruh Konsentrasi NaCl Terhadap Kadar Protein}

Konsentrasi $\mathrm{NaCl}$ memberikan pengaruh yang berbeda sangat nyata $(\mathrm{P}<0.01)$ terhadap kadar protein. Hasil uji beda rata-rata untuk menunjukkan tingkat perbedaan masingmasing taraf dapat dilihat pada Tabel 1 .

Tabel 7. Hasil Uji Beda Rata-Rata Pengaruh Konsentrasi NaCl Terhadap Kadar Protein

\begin{tabular}{|c|c|c|c|c|c|c|}
\hline \multirow{2}{*}{$\begin{array}{c}\text { Perlakuan } \\
(\mathrm{N})\end{array}$} & \multirow{2}{*}{\multicolumn{2}{|c|}{ Rataan Jarak }} & \multicolumn{2}{|c|}{ LSR } & \multicolumn{2}{|c|}{ Notasi } \\
\hline & & & 0,05 & 0,01 & 0,05 & 0,01 \\
\hline $\mathrm{N}_{1}=1$ & 22.573 & - & - & - & $\mathrm{d}$ & D \\
\hline $\mathrm{N}_{2}=2$ & 23.982 & 2 & 1.008 & 1.388 & $a b c$ & $\mathrm{ABC}$ \\
\hline $\mathrm{N}_{3}=3$ & 24.102 & 3 & 1.059 & 1.059 & $a b$ & $A B$ \\
\hline $\mathrm{N}_{4}=4$ & 25.119 & 4 & 0.086 & 1.086 & $\mathrm{a}$ & A \\
\hline
\end{tabular}

Berdasakan Tabel 1 dapat dilihat bahwa $\mathrm{N}_{4}$ berbeda tidak nyata dengan $\mathrm{N}_{3}, \mathrm{~N}_{2}$, dan berbeda sangat nyata dengan $\mathrm{N}_{1} . \mathrm{N}_{3}$ berbeda tidak nyata dengan $\mathrm{N}_{2}$ dan berbeda sangat nyata dengan $\mathrm{N}_{1}$. $\mathrm{N}_{2}$ berbeda sangat nyata dengan $\mathrm{N}_{1}$. Kadar protein tertinggi terdapat pada perlakuan $\mathrm{N}_{4}$ yaitu sebesar 25,119\% dan terendah terdapat pada perlakuan $\mathrm{N}_{1}$ yaitu sebesar 22,573\%. untuk lebih jelasnya dapat dilihat pada Gambar 1.

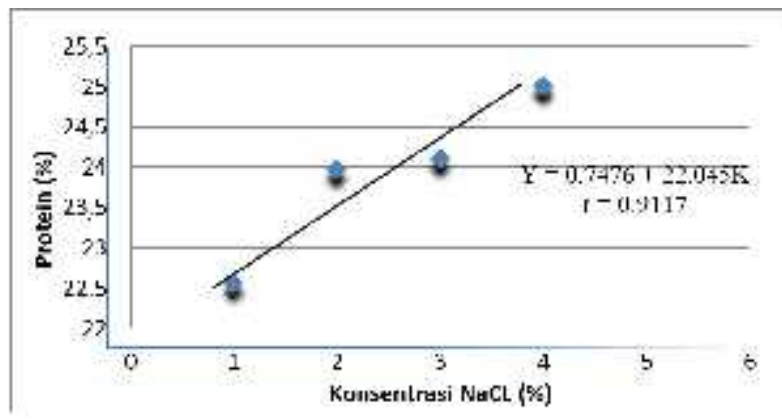

Gambar 1. Hubungan konsentrasi $\mathrm{NaCl}$ dengan kadar protein

Dari Gambar 1 dapat menunjukkan konsentrasi $\mathrm{NaCl}$ berpengaruh terhadap kadar protein. Kadar protein tertinggi pada perlakuan $\mathrm{N}_{4}$ (25,119 \%). Menurut Alfusia dkk, 2012, terjadinya peningkatan kadar protein, karena limbah kubis mengandung akteri asam laktat yang dapat menghambat pertumbuhan bakteri lain, dengan cara memproduksi protein 
tersebut yang disebut bakteriosin. Salah satu contoh bakteriosin yang dikenal luas adalah nisin yang diproduksi oleh Laktobacillus lactis $s p$. Bakteri Asam laktat ini juga dapat dikatakan sebagai bahan pengawet zat anti mikrobia penyebab kerusakan protein. Semakin tinggi konsentrasi $\mathrm{NaCl}$ maka kandungan Asam laktat yang dihasilkan semakin meningkat, sehingga protein dalam daging ikan dapat dipertahankan tetap tinggi. Kemampuan suatu bahan pengawet untuk menghambat pertumbuhan mikroba yang dipengaruhi oleh beberapa faktor, diantaranya konsentrasi zat pengawet, sifat-sifat fisik dan kimia makanan termasuk kadar air, $\mathrm{pH}$, jenis dan jumlah senyawa di dalamnya, suhu lingkungan serta waktu penyimpanan (Fardiaz, 1989).

\section{Pengaruh Lama Penyimpanan terhadap Kadar Protein}

Lama penyimpanan memberikan pengaruh yang berbeda sangat nyata $(\mathrm{P}<0.01)$ terhadap kadar protein. Hasil uji beda rata-rata untuk menunjukkan tingkat perbedaan masingmasing taraf dapat dilihat pada Tabel 2 .

Tabel 2. Hasil uji beda rata-rata pengaruh lama penyimpanan terhadap protein

\begin{tabular}{ccccccc} 
Perlakuan & \multirow{2}{*}{\begin{tabular}{c}
\multirow{2}{*}{ R } \\
R
\end{tabular}} & & \multicolumn{2}{c}{ LSR } & \multicolumn{2}{c}{ Notasi } \\
\cline { 3 - 7 } & & 0,05 & 0,01 & 0,05 & 0,01 \\
\hline $\mathrm{P}_{1}=1$ & 5,853 & - & - & - & $\mathrm{a}$ & $\mathrm{A}$ \\
$\mathrm{P}_{2}=3$ & 4,748 & 2 & 1.008 & 1.388 & $\mathrm{ab}$ & $\mathrm{AB}$ \\
$\mathrm{P}_{3}=5$ & 3,316 & 3 & 1.059 & 1.059 & $\mathrm{bc}$ & $\mathrm{BC}$ \\
$\mathrm{P}_{4}=7$ & 1,780 & 4 & 0.086 & 1.086 & $\mathrm{~d}$ & $\mathrm{D}$ \\
\hline
\end{tabular}

Keterangan: Huruf yang berbeda pada kolom notasi menunjukkan pengaruh yang berbeda nyata pada taraf $5 \%$ dan berbeda sangat nyata pada taraf $1 \%$

Dari Tabel 2 dapat dilihat bahwa $P_{1}$ berbeda tidak nyata dengan $P_{2}$, berbeda sangat nyata dengan $\mathrm{P}_{3}$, dan $\mathrm{P}_{4} . \mathrm{P}_{2}$ berbeda tidak nyata dengan $\mathrm{P}_{3}$ dan berbeda sangat nyata dengan $\mathrm{P}_{4}$. Sedangkan $\mathrm{P}_{3}$ berbeda sangat nyata dengan $\mathrm{P}_{4}$. Protein tertinggi terdapat pada perlakuan $\mathrm{P}_{1}$ yaitu sebesar $25,853 \%$, dan terendah terdapat pada perlakuan $\mathrm{P}_{4}$ yaitu sebesar $21.780 \%$. untuk lebih jelasnya dapat dilihat pada Gambar 2.

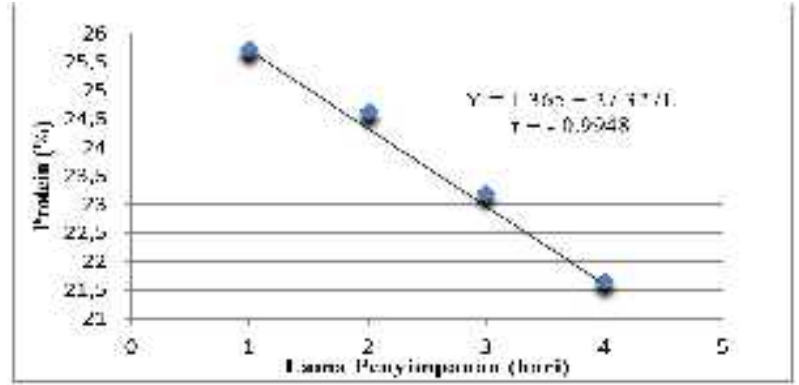

Gambar 2. Hubungan lama penyimpanan dengan Protein protein

Dari Gambar 2 dapat dilihat bahwa lama penyimpanan berpengaruh terhadap protein. Protein tertinggi pada perlakuan $\mathrm{P}_{1}(25,853 \%)$. Protein dikatakan rusak atau terdenaturasi apabila susunan ruang atau rantai polipeptida suatu molekul protein berubah. Sebagian protein mudah mengalami denaturasi jika ikatan-ikatan yang membentuk konfigurasi molekul tersebut rusak, molekul akan mengembang. Kadang-kadang perubahan ini memang dikehendaki dalam pengolahan makanan, tetapi sering pula dianggap merugikan sehingga perlu dicegah. Semakin lama penyimpanan ikan dengan larutan limbah kubis maka protein pada ikan mas mengalami penurunan diakibatkan penurunan jumlah BAL (Bakteri Asam Laktat) selama proses penyimpanan berlangsung, karena nutrient yang terdapat pada substrat berkurang, berkurangnya jumlah nutrient akan mengakibatkan persaingan diantara bakteri Asam Laktat dan akhirnya nutrisi dalam subtrat menjadi sangat terbatas (Martin, 2010).

\section{Kadar Air}

\section{Pengaruh Konsentrasi NaCl Terhadap Kadar Air}

Konsentrasi $\mathrm{NaCl}$ memberikan pengaruh yang berbeda sangat nyata $(P<0.01)$ terhadap kadar air. Hasil uji beda rata-rata untuk menunjukkan tingkat perbedaan masingmasing taraf dapat dilihat pada Tabel 3

Tabel 3. Hasil uji beda rata-rata pengaruh konsentrasi $\mathrm{NaCl}$ terhadap kadar air

\begin{tabular}{cccccccc}
\hline $\begin{array}{c}\text { Perlakuan } \\
\text { (K) }\end{array}$ & \multirow{2}{*}{ Rataan Jarak } & \multicolumn{2}{c}{ LSR } & \multicolumn{2}{c}{ Notasi } \\
\cline { 3 - 7 } & & & 0,05 & 0,01 & 0,05 & 0,01 \\
\hline $\mathrm{N}_{1}=1$ & 81,620 & - & - & - & $\mathrm{a}$ & $\mathrm{A}$ \\
$\mathrm{N}_{2}=2$ & 81,536 & 2 & 0,090 & 0,124 & $\mathrm{ab}$ & $\mathrm{AB}$ \\
$\mathrm{N}_{3}=3$ & 81,459 & 3 & 0,095 & 0,130 & $\mathrm{bc}$ & $\mathrm{BC}$ \\
$\mathrm{N}_{4}=4$ & 81,432 & 4 & 0,097 & 0,134 & $\mathrm{bcd}$ & $\mathrm{BCD}$ \\
\hline Keterangan: & Huruf & yang & berbeda & pada & kolom & notasi \\
menunjukkan pengaruh yang berbeda nyata pada taraf 5\% \\
dan berbeda sangat nyata pada taraf 1\%
\end{tabular}


Berdasakan Tabel 3 dapat dilihat bahwa $\mathrm{N}_{1}$ berbeda tidak nyata dengan $\mathrm{N}_{2}$, berbeda sangat nyata dengan $\mathrm{N}_{3}$ dan berbeda sangat nyata dengan $\mathrm{N}_{4} . \mathrm{N}_{2}$ berbeda tidak nyata dengan $\mathrm{N}_{3}$ dan $\mathrm{N}_{4} . \mathrm{N}_{3}$ berbeda tidak nyata dengan $\mathrm{N}_{4}$. Kadar air tertinggi terdapat pada perlakuan $\mathrm{N}_{1}$ yaitu sebesar $81,620 \%$, dan terendah terdapat pada perlakuan $\mathrm{N}_{4}$ yaitu sebesar $81,432 \%$. untuk lebih jelasnya dapat dilihat pada Gambar 3.

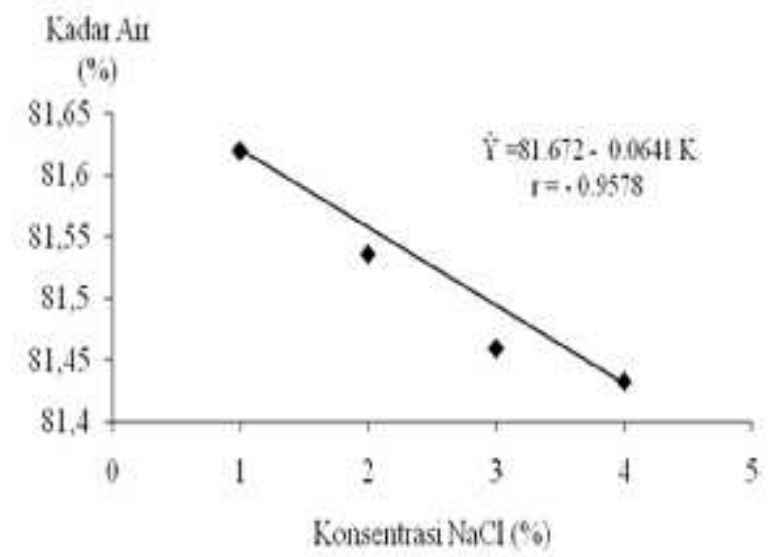

Gambar 3. Hubungan Konsentrasi $\mathrm{NaCl}$ dengan Kadar Air

Dari Gambar 3 dapat menunjukkan konsentrasi $\mathrm{NaCl}$ (Natrium Klorida) berpengaruh terhadap kadar air. Kadar air tertinggi terletak pada $\mathrm{N}_{1} \quad(81,620 \%)$. Terjadinya penurunan kadar air, karena Limbah kubis yang telah difermentasimengandung asam laktat yang dapat mengikat air dari dalam daging ikan, sehingga air dalam daging akan semakin berkurang. Penambahan $\mathrm{NaCl}$ (Natrium Klorida) merupakan tahap penting dalam fermentasi limbah kubis, karena penambahan $\mathrm{NaCl}$ ini juga berguna untuk menarik air, baik dari jaringan daging ikan maupun dari dalam sel mikrobia, sehingga dapat menyeleksi mikrobia yang tidak dikehendaki dan mikrobia perusak yang tidak tahan garam. Sehingga selain itu garam dapat berfungsi sebagai pengendali aktifitas fermentasi (Deshrohsier, 1969).

\section{Pengaruh Lama Penyimpanan terhadap Kadar Air}

Lama penyimpanan memberikan pengaruh yang berbeda sangat nyata $(\mathrm{P}<0.01)$ terhadap kadar air. Hasil uji beda rata-rata untuk menunjukkan tingkat perbedaan masingmasing taraf dapat dilihat pada Tabel 4 .
Tabel 4. Hasil Uji Beda Rata-Rata Pengaruh Penyimpanan Terhadap Kadar Air

\begin{tabular}{|c|c|c|c|c|c|c|}
\hline \multirow{2}{*}{$\begin{array}{l}\text { Perlakuan } \\
\text { (L) }\end{array}$} & \multirow{2}{*}{\multicolumn{2}{|c|}{ Rataan Jarak }} & \multicolumn{2}{|c|}{ LSR } & \multicolumn{2}{|c|}{ Notasi } \\
\hline & & & 0,05 & 0,01 & 0,05 & 0,01 \\
\hline$P_{1}=1$ & 82,164 & - & & & $\mathrm{a}$ & A \\
\hline$P_{2}=3$ & 81,763 & 2 & 0,090 & 0,124 & b & B \\
\hline$P_{3}=5$ & 81,26 & 3 & 0,095 & 0,130 & c & $\mathrm{C}$ \\
\hline$P_{4}=7$ & 80,854 & 4 & 0,097 & 0,134 & $\mathrm{~d}$ & $\mathrm{D}$ \\
\hline
\end{tabular}

Keterangan: Huruf yang berbeda pada kolom notasi menunjukkan pengaruh yang berbeda nyata pada taraf 5\% dan berbeda sangat nyata pada taraf 1\%

Dari Tabel 4 dapat dilihat bahwa $\mathrm{P}_{1}$ berbeda sangat nyata dengan $\mathrm{P}_{2}, \mathrm{P}_{3}$, dan $\mathrm{P}_{4} . \mathrm{P}_{2}$ berbeda sangat nyata dengan $\mathrm{P}_{3}$ dan $\mathrm{P}_{4} . \mathrm{P}_{3}$ berbeda sangat nyata dengan $\mathrm{P}_{4}$. Kadar air tertinggi terdapat pada perlakuan $\mathrm{P}_{1}$ yaitu sebesar $82,164 \%$, dan terendah terdapat pada perlakuan $\mathrm{P}_{4}$ yaitu sebesar $80,854 \%$. untuk lebih jelasnya dapat dilihat pada Gambar 4 .

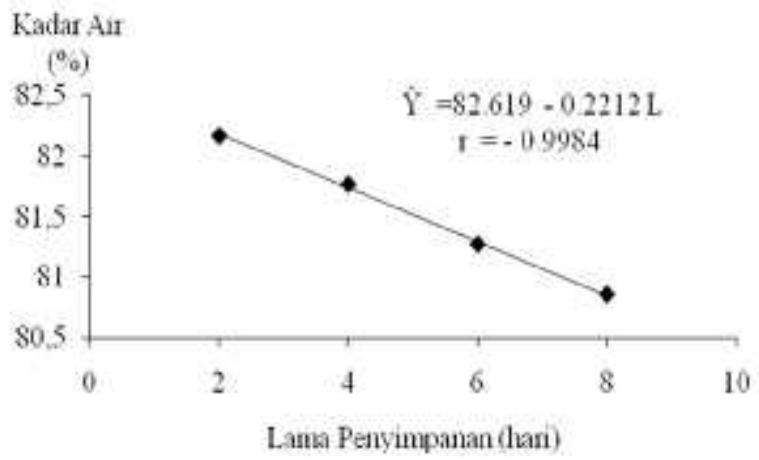

Gambar 4. Hubungan lama penyimpanan dengan kadar air

Dari Gambar 4 dapat dilihat bahwa lama penyimpanan berpengaruh terhadap kadar air. Kadar air tertinggi terletak pada $\mathrm{P}_{1}$ (82,164\%).Semakin besar konsentrasi $\mathrm{NaCl}$ dan waktu penyimpanan yang dilakukan maka kadar airnya semakin menurun.Kadar air terbaik terjadi pada konsentrasi natrium klorida $(\mathrm{NaCl})$ pada waktu penyimpanan 2 hari yaitu sebesar 82,164\% (Hasibuan, 2014). Hal ini disebabkan oleh ion-ion garam yang memiliki kelarutan lebih besar dibandingkan dengan protein sehingga ion garam akan menarik molekul air dari protein enzim. Kadar air bebas yang rendah menghambat difusi enzim atau substrat, akibatnya hidrolisis hanya terjadi pada bagian substrat yang langsung berhubungan dengan enzim (Winarno, 1983). Hal ini juga dapat disebabkan oleh kemampuan garam dapat mengikat air keluar dari jaringan daging ikan (garam bersifat higrokopis) pada saat proses fermentasi. (Borgstrom, 1995) juga mengatakan adanya garam dalam ikan akan 
mendenaturasi protein, sehingga terjadi koagulasi yang dapat membebaskan air.

\section{Tekstur}

\section{Pengaruh Konsentrasi $\mathrm{NaCl}$ Terhadap Tekstur}

Konsentrasi $\mathrm{NaCl}$ memberikan pengaruh yang berbeda sangat nyata $(\mathrm{P}<0.01)$ terhadap tekstur. Hasil uji beda rata-rata untuk menunjukkan tingkat perbedaan masingmasing taraf dapat dilihat pada Tabel 5 .

Tabel 5. Hasil uji beda rata-rata pengaruh konsentrasi $\mathrm{NaCl}$ terhadap tekstur

\begin{tabular}{cccccccc}
\hline \multirow{2}{*}{$\begin{array}{c}\text { Perlakuan } \\
\text { (K) }\end{array}$} & \multirow{2}{*}{ Rataan Jarak } & \multicolumn{2}{c}{ LSR } & \multicolumn{2}{c}{ Notasi } \\
\cline { 3 - 7 } & & & 0,05 & 0,01 & 0,05 & 0,01 \\
\hline $\mathrm{N}_{1}=1$ & 1.700 & - & - & - & $\mathrm{a}$ & $\mathrm{A}$ \\
$\mathrm{N}_{2}=2$ & 1.950 & 2 & 0,187 & 0,120 & $\mathrm{~b}$ & $\mathrm{AB}$ \\
$\mathrm{N}_{3}=3$ & 2.238 & 3 & 0,091 & 0,126 & $\mathrm{c}$ & $\mathrm{BC}$ \\
$\mathrm{N}_{4}=4$ & 2,425 & 4 & 0,093 & 0,129 & $\mathrm{~d}$ & $\mathrm{D}$ \\
\hline
\end{tabular}

Keterangan: Huruf yang berbeda pada kolom notasi menunjukkan pengaruh yang berbeda nyata pada taraf 5\% dan berbeda sangat nyata pada taraf $1 \%$

Berdasakan Tabel 5 dapat dilihat bahwa $\mathrm{N}_{1}$ berbeda tidak dengan $\mathrm{N}_{2}$, berbeda sangat nyata $\mathrm{N}_{3}$ dan $\mathrm{N}_{4} . \mathrm{N}_{2}$ berbeda tidak nyata dengan $\mathrm{N}_{3}$ dan berbeda sangat nyata $\mathrm{N}_{4} \cdot \mathrm{N}_{3}$ berbeda sangat nyata dengan $\mathrm{N}_{4}$. Tekstur tertinggi terdapat pada perlakuan $\mathrm{N}_{4}$ yaitu sebesar 2,425 dan terendah terdapat pada perlakuan $\mathrm{N}_{1}$ yaitu sebesar 1,700. untuk lebih jelasnya dapat dilihat pada Gambar 5

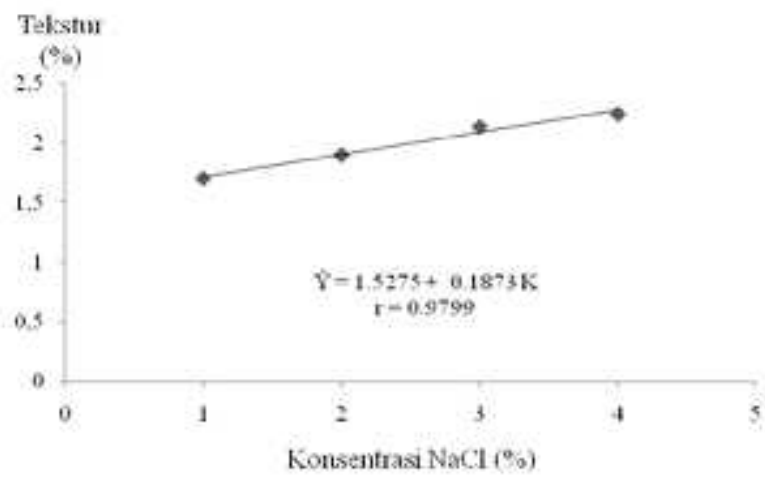

Gambar 5. Hubungan Konsentrasi $\mathrm{NaCl}$ dengan Tekstur

Dari Gambar 5 dapat menunjukkan konsentrasi $\mathrm{NaCl}$ berpengaruh terhadap tekstur. Tekstur tertinggi terletak pada $\mathrm{N}_{4}$ $(2,425)$. Terjadinya peningkatan tekstur, karena saat ini bakteri asam laktat digunakan untuk pengawet dan mempertahankan tekstur pada bahan pangan semakin tinggi konsentrasi $\mathrm{NaCl}$ maka semakin baik komponen aktif yang terekstrak dan dapat mempertahankan tekstur dari ikan (Agus, 2012). Hasil penelitian
(Dwihandita, 2009), menyatakan selama pengolahan bahan pangan akan mengalami perubahan sifat fisik dan kimia. Salah satunya adalah perubahan sensori seperti tekstur, aroma, warna dan rasa. Perubahan tekstur ditentukan oleh komponen alami pada bahan pangan seperti air, lemak, protein dan karbohidrat.

\section{Pengaruh Lama Penyimpanan terhadap Tekstur}

Lama penyimpanan memberikan pengaruh yang berbeda sangat nyata $(P<0.01)$ terhadap tekstur. Hasil uji beda rata-rata untuk menunjukkan tingkat perbedaan masingmasing taraf dapat dilihat pada Tabel 6.

Tabel 6. Hasil uji beda rata-rata pengaruh lama penyimpanan terhadap tekstur

\begin{tabular}{ccccccc} 
Perlakuan & \multirow{2}{*}{ Rataan Jarak } & \multicolumn{2}{c}{ LSR } & \multicolumn{2}{c}{ Notasi } \\
\cline { 4 - 7 } (L) & & & 0,05 & 0,01 & 0,05 & 0,01 \\
\hline $\mathrm{P}_{1}=1$ & 1,813 & - & - & - & $\mathrm{d}$ & $\mathrm{D}$ \\
$\mathrm{P}_{2}=3$ & 1,975 & 2 & 0,117 & 0,161 & $\mathrm{c}$ & $\mathrm{C}$ \\
$\mathrm{P}_{3}=5$ & 2,100 & 3 & 0,123 & 0,169 & $\mathrm{~b}$ & $\mathrm{~B}$ \\
$\mathrm{P}_{4}=7$ & 2,275 & 4 & 0,126 & 0,174 & $\mathrm{a}$ & $\mathrm{A}$ \\
\hline
\end{tabular}

Keterangan: Huruf yang berbeda pada kolom notasi menunjukkan pengaruh yang berbeda nyata pada taraf 5\% dan berbeda sangat nyata pada taraf 1\%

Dari Tabel 6 dapat dilihat bahwa $\mathrm{P}_{4}$ berbeda sangat nyata dengan $\mathrm{P}_{3}, \mathrm{P}_{2}$ dan $\mathrm{P}_{1} . \mathrm{P}_{3}$ berbeda sangat nyata dengan $\mathrm{P}_{2}$ dan $\mathrm{P}_{1} \cdot \mathrm{P}_{2}$ berbeda sangat nyata dengan $P_{1}$. Tekstur tertinggi terdapat pada perlakuan $\mathrm{P}_{4}$ yaitu sebesar 2,275 dan terendah terdapat pada perlakuan $\mathrm{P}_{1}$ yaitu sebesar 1,813 . untuk lebih jelasnya dapat dilihat pada Gambar 6.

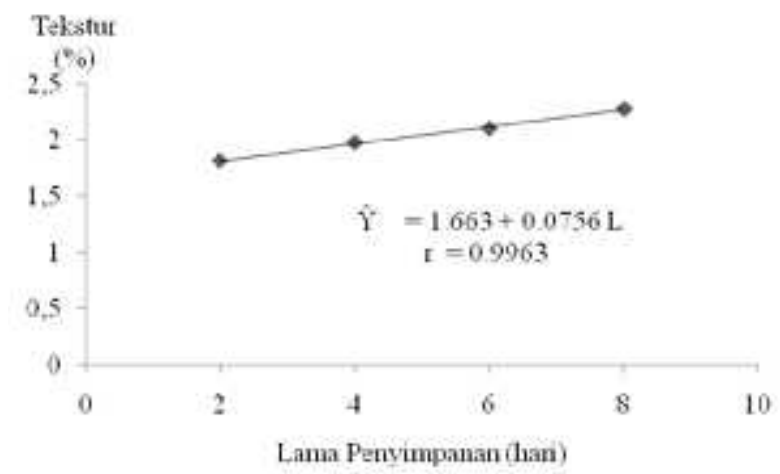

Gambar 6. Hubungan Lama Penyimpanan dengan Tekstur

Dari Gambar 6 dapat dilihat bahwa lama penyimpanan berpengaruh terhadap tekstur. Tekstur tertinggi terletak pada $\mathrm{P}_{4} \quad(2,275)$. Semakin lama penyimpanandengan ekstrak limbah kubis maka tekstur dari ikan semakin disukai oleh panelis. Penyimpanan pada suhu 
rendah diketahui dapat memperlambat proses kemunduran mutu dan memperpanjang masa hidup jaringan-jaringan di dalam bahan pangan dengan menghambat aktivitas enzim dan bakteri pembusuk. Namun, beberapa bakteri pembusuk mampu bertahan pada penyimpanan suhu rendah karena proses ini bersifat menghambat pertumbuhan bukan untuk membunuh ataumenghentikan mikroorganisme sama sekali. Oleh karena itu bakteri Asam Laktat digunakan sebagai bahan pengawet untuk memperbaiki tekstur dari ikan (Dwihandita, 2009).

\section{Organoleptik Aroma}

\section{Pengaruh Konsentrasi Nacl Terhadap Organoleptik Aroma}

Konsentrasi $\mathrm{NaCl}$ memberikan pengaruh yang berbeda sangat nyata $(\mathrm{P}<0.01)$ terhadap aroma. Hasil uji beda rata-rata untuk menunjukkan tingkat perbedaan masingmasing taraf dapat dilihat pada Tabel 7.

Tabel 7. Hasil uji beda rata-rata pengaruh konsentrasi NaClterhadap Aroma

\begin{tabular}{ccccccc}
\hline \multirow{2}{*}{$\begin{array}{c}\text { Perlakuan } \\
\text { (K) }\end{array}$} & \multirow{2}{*}{ Rataan Jarak } & \multicolumn{2}{c}{ LSR } & \multicolumn{2}{c}{ Notasi } \\
\cline { 3 - 7 } & & & 0,05 & 0,01 & 0,05 & 0,01 \\
\hline $\mathrm{N}_{1}=1$ & 1,813 & - & - & - & $\mathrm{d}$ & $\mathrm{D}$ \\
$\mathrm{N}_{2}=2$ & 2,063 & 2 & 0,158 & 0,218 & $\mathrm{c}$ & $\mathrm{C}$ \\
$\mathrm{N}_{3}=3$ & 2,313 & 3 & 0,169 & 0,229 & $\mathrm{~b}$ & $\mathrm{~B}$ \\
$\mathrm{~N}_{4}=4$ & 2,400 & 4 & 0,170 & 0,234 & $\mathrm{a}$ & $\mathrm{A}$ \\
\hline
\end{tabular}

Keterangan: Huruf yang berbeda pada kolom notasi menunjukkan pengaruh yang berbeda nyata pada taraf 5\% dan berbeda sangat nyata pada taraf $1 \%$

Berdasakan Tabel 7 dapat dilihat bahwa $\mathrm{N}_{4}$ berbeda sangat nyata dengan $\mathrm{N}_{3}, \mathrm{~N}_{2}$, dan $\mathrm{N}_{1} . \mathrm{N}_{3}$ berbeda sangat nyata dengan $\mathrm{N}_{2}$ dan $\mathrm{N}_{1} . \mathrm{N}_{2}$ berbeda sangat nyata dengan $\mathrm{N}_{1}$. Aroma tertinggi terdapat pada perlakuan $\mathrm{N}_{4}$ yaitu sebesar 2,400, dan terendah terdapat pada perlakuan $\mathrm{N}_{1}$ yaitu sebesar 1,813. untuk lebih jelasnya dapat dilihat pada Gambar 7

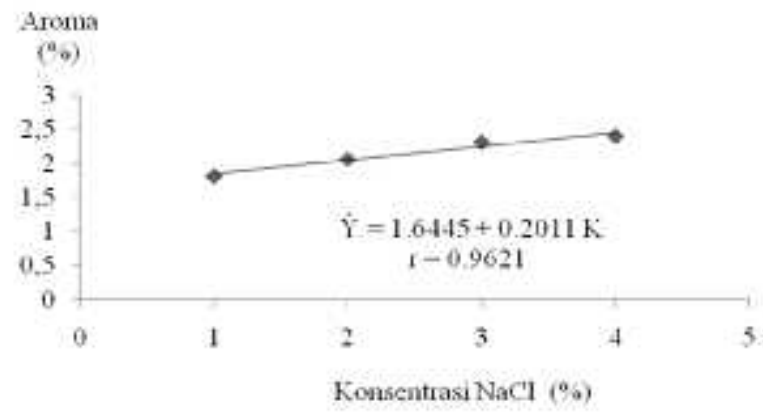

Gambar 7. Hubungan konsentrasi $\mathrm{NaCl}$ dengan aroma
Dari Gambar 7 dapat menunjukkan konsentrasi $\mathrm{NaCl}$ berpengaruh terhadap aroma. Aroma tertinggi terletak pada $\mathrm{N}_{4} \quad(2,400)$. Terjadinya peningkatan Aroma, karena adanya garam yang digunakan dalam fermentasi sangat mempengaruhi produk akhir, disebabkan oleh laju enzimatik garam yang juga dapat menghambat pertumbuhan dan pengembangan bau (aroma) yang menyengat. Bakteri Asam Laktat adalah kelompok bakteri yang mampu mengubah karbohidrat pada bahan menjadi Asam Laktat yang menghasilkan aroma menyengat, Namun penambahan $\mathrm{NaCl}$ berpengaruh dalam fermentasi yang sangat bermanfaat untuk mendapatkan hasil fermentasi limbah kubis yang baik. Semakin banyak penambahan $\mathrm{NaCl}$ mengurangi aroma yang begitu menyengat (Efendi, 1992).

\section{Pengaruh Lama Penyimpanan Terhadap Organoleptik Aroma}

Konsentrasi $\mathrm{NaCl}$ memberikan pengaruh yang berbeda sangat nyata $(\mathrm{P}<0.01)$ terhadap kadar protein. Hasil uji beda rata-rata untuk menunjukkan tingkat perbedaan masingmasing taraf dapat dilihat pada Tabel 8.

Tabel 8. Hasil uji beda rata-rata pengaruh lama penyimpanan terhadap aroma

\begin{tabular}{|c|c|c|c|c|c|c|}
\hline \multirow{2}{*}{$\begin{array}{l}\text { Perlakuan } \\
\text { (L) }\end{array}$} & \multirow{2}{*}{ Rataan } & \multirow{2}{*}{ Jarak } & \multicolumn{2}{|c|}{ LSR } & \multicolumn{2}{|c|}{ Notasi } \\
\hline & & & 0,05 & 0,01 & 0,05 & 0,01 \\
\hline $\mathrm{P}_{1}=1$ & 1,825 & - & & 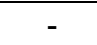 & $\mathrm{d}$ & CD \\
\hline & & 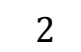 & 0,158 & 0,218 & c & BC \\
\hline$P_{3}=5$ & 2,2 & 3 & 0,169 & 0,229 & b & $\mathrm{AB}$ \\
\hline$P_{4}=7$ & 2,425 & 4 & 0,170 & 0,234 & $\mathrm{a}$ & A \\
\hline
\end{tabular}

Keterangan: Huruf yang berbeda pada kolom notasi menunjukkan pengaruh yang berbeda nyata pada taraf 5\% dan berbeda sangat nyata pada taraf 1\%

Berdasarkan Tabel 8 dapat dilihat bahwa $\mathrm{P}_{4}$ berbeda tidak nyata dengan $\mathrm{P}_{3}$, dan berbeda sangat nyata dengan $\mathrm{P}_{2}$, dan $\mathrm{P}_{1}$. $\mathrm{P}_{3}$ berbeda tidak nyata dengan $P_{2}$, dan berbeda sangat nyata dengan $\mathrm{P}_{1} . \mathrm{P}_{2}$ berbeda tidak nyata dengan $\mathrm{P}_{1}$. Aroma tertinggi terdapat pada perlakuan $\mathrm{P}_{4}$ yaitu sebesar 2,425 dan terendah terdapat pada perlakuan $\mathrm{P}_{1}$ yaitu sebesar 1,825 . Untuk lebih jelasnya dapat dilihat pada Gambar 8. 


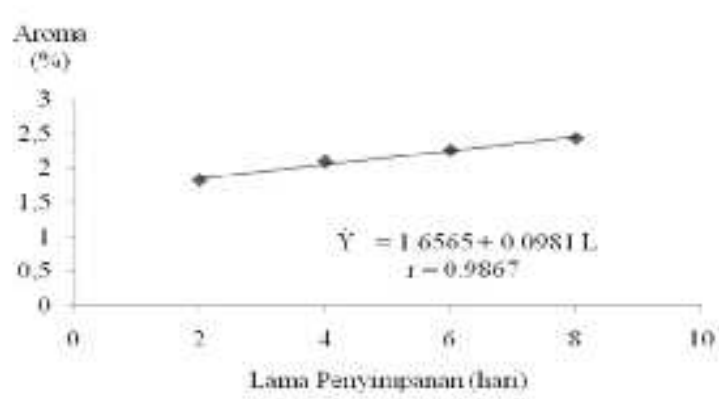

Gambar 8. Hubungan lama penyimpanan dengan aroma

Dari Gambar 8 dapat menunjukkan Lama penyimpanan berpengaruh terhadap aroma. aroma tertinggi terletak pada $\mathrm{P}_{4} \quad(2,425)$. Terjadinya peningkatan aroma dikarenakan dengan adanya penurunan bakteri aerob akibat turunnya $\mathrm{pH}$ medium dan bakteorosin yang dihasilkan oleh bakteri asam laktat, maka selama penyimpanan mengalami sedikit perubahan. Semakin lama disimpan pada suhu ruangan aroma dari ikan tidak begitu mengalami perubahan yang drastis, diakibatkan juga karena adanya penambahan $\mathrm{NaCl}$ (Red, 2008).

\section{Warna}

Pengaruh Konsentrasi NaCl Terhadap Warna

Konsentrasi $\mathrm{NaCl}$ memberikan pengaruh yang berbeda tidak nyata $(\mathrm{P}>0.05)$ terhadap warna. Sehingga pengujian selanjutnya tidak dilakukan.

\section{Pengaruh Lama Penyimpanan Terhadap Warna}

Lama Penyimpananmemberikan pengaruh yang berbeda tidak nyata $(\mathrm{P}>0.05)$ terhadap warna. Sehingga pengujian selanjutnya tidak dilakukan.

\section{Pengaruh Interaksi Perlakuan Terhadap Warna}

Interaksi perlakuan berpengaruh berbeda tidak nyata $(\mathrm{P}>0.05)$ terhadap warna. Sehingga pengujian selanjutnya tidak dilakukan

\section{KESIMPULAN}

1. Konsentrasi $\mathrm{NaCl}$ memberikan pengaruh yang berbeda sangat nyata terhadap kadar protein, kada air, uji organoleptik tekstur dan aroma, dan berbeda tidak nyata pada uji organoleptik warna.

2. Lama penyimpanan memberikan pengaruh yang berbeda sangat nyata terhadap kadar protein, kadar air, uji organoleptik tekstur dan aroma, dan berbeda tidak nyata pada uji organoleptik warna.

3. Limbah kubis (Brassica oleracea) dari hasil penelitian ini bisa digunakan sebagai bahan pengawet alami ikan Mas (Cyprinus carpio L).

4. Interaksi konsentrasi $\mathrm{NaCl}$ dengan lama penyimpanan tidak berbeda nyata pada semua parameter yang diuji.

\section{SARAN}

Disarankan untuk melakukan penelitian dengan cara fermentasi menggunakan bahan limbah sayuran jenis lain yang kemungkinan lebih baik dari kubis dan dinaikkan konsentrasi $\mathrm{NaCl}$ /garam untuk limbah sayur kubis atau sayuran lainnya.

\section{Ucapan Terima Kasih}

Universitas Muhammadiyah Sumatera Utara dan Lembaga Penelitian dan Pengabdian Masyarakat (LP2M) dalam pendanaan penelitian internal UMSU

\section{DAFTAR PUSTAKA}

Agus K, 2004. Mikrobiologi Terapan, Universitas Muhammadiyah Malang. Malang, 2012. Penambahan Bakteri asam Laktat dan Cendawan Aspergillus Niger dalam Pengolahan Fermentasi kacang kedelai. http//Agus

Krisno.blog.Wedpress.com//12//01//07. Diakses pada tanggal 6 Desember 2014.

Amin, 2001. Cara Fermentasi. Teknologi Pangan dan Giji. IPB. Bogor

Apriyanto, 1984, Pengolahan dengan Penambahan Bahan Kimia, Institut Pertanian Bogor, Bogor.

Buckle, K.A., R.A. Edward., G.H. Fleet dan M Wootton. 1987. Ilmu Teknologi Pangan. Terjemahan dari: Hari Purnomo dan Hadiono. Penerbit Universitas Indonesia Press. Jakarta.

1987. Ilmu Teknologi Pangan. Penerapan pengawetan makanan. Penerbit UI Press. Jakarta.

Fardiaz, S, 1987. Fisiologi Fermentasi. Pusat Antar Universitas Institut Pertanian Bogor (IPB). Bogor. 
1989. Karakteristik Sifat Fisik dan Bahan Kimia Pangan. IPB. Bogor.

Harjono, 1996.Melirik Bisnis Tani Kubis Bunga. CV. Aneka, Solo.

http://kesehatan.kompasiana.com/makanan/2 012/03/30/ikan-mas-dan-kesehatan$\underline{\text { tubuh }}$

Irawan, 1992. Pembuatan Filet Ikan. Kumpulan Hasil-hasil Penelitian Pasca Panen. ITB. Bandung. 1995. Teknologi Hasil Perikanan. UGM. Yokyakarta.

Leni, 2004. Keunggulan Makanan Fermentasi, Cakrawala-Pikiran Rakyat Cyber. MediaLiberty.

Murniyati, A. S dan Sunarman.2000. Pendinginan Pembekuan dan Pengawetan Ikan. Kanisius. Yogyakarta.

Mustakin, s. 1987. Mempelajari kemampuan lactobacillus casei dalam memproduksi asam laktat dari tetes tebu dalam limbah cair tebu dengan system kultur batch.IPB. Bogor.

Pracaya, 1994. Kol Alias Kubis, Penebar Swadaya, Jakarta. Pustaka.

Siswono, 2012. Ikan Air Tawar Kaya Protein dan Vitamin, www.gizi.net.

Soekarto, 1982. Penilaian Organoleptik untuk Industri Pangan dan Hasil Pertanian. IPB. Bogor.

Sudarmadji, S., B. Haryono dan Suhardi, 1987.Analisis Bahan Pangan Pertanian. Liberty. Yogyakarta.

Sutriah, K dan A, Sjahriza, 2007. Fermentasi. http :/Id. wikipedia. com.[diakses pada 8 September 2014]Universitas Indonesia Press. Jakarta. 365 hlm.

Wikepedia, 2010. Kubis. http://id.wikipedia.org/wiki/Kubis. Diakses pada tanggal 1 Desember 2014.

2012.BAL.http://id.wikipedia.org/wiki/B akteri_asam_laktat. Diakses pada tanggal 1 Desember 2014.

Winarno,F.G.I, 1983. Enzim Pangan. Gramedia. Jakarta.

1993. Pangan, Gizi, Teknologi dan konsumsi. Jakarta; Gramedia, 2004. Kimia Pangan dan Gizi, Gramedia Pustaka Utama, Jakarta.

Zaifbio, 2009. Dasar - dasar Mikrobiologi. Unniversitas Indonesia. Jakarta. 